\title{
MAKNA HIDUP PADA MAHASISWA RANTAU: ANALISIS FAKTOR EKSPLORATORI SKALA MAKNA HIDUP
}

\author{
Diah Dinar Utami dan Farida Agus Setiawati \\ Universitas Negeri Yogyakarta \\ e-mail: diahdinar31@gmail.com
}

\begin{abstract}
Abstrak
Pemaknaan hidup pada manusia dapat dihadirkan dari berbagai macam peristiwa, salah satunya adalah masuknya seseorang ke dalam lingkungan baru yang membuat individu memiliki pandangan yang baru ataupun pengalaman yang baru terhadap budaya tersebut. Instrumen pemaknaan hidup yang diuji peneliti mengukur makna hidup yang dihasilkan oleh mahasiswa rantau. Nilai reliabilitas yang dihasilkan oleh instrumen ini terbilang tinggi yaitu 0,924. Hasil analisis faktor eksploratori yang dilakukan oleh peneliti menghasilkan lima komponen penyusun makna hidup yang tersusun dalam 34 item.
\end{abstract}

Kata kunci: makna hidup, mahasiswa merantau

\section{THE MEANING IN LIFE OF OVERSEAS STUDENTS: A EXPLORATORY FACTOR ANALYSIS OF THE MEANING IN LIFE}

\begin{abstract}
The meaning in life in humans can be presented from various kinds of events, one of which is the entry of a person into a new environment that makes individuals have new views or new experiences with that culture. The instrument of meaning in life that was tested by researchers measured the meaning in life produced by overseas students. The reliability value produced by this instrument is relatively high at 0.924. The results of the exploratory factor analysis carried out by the researchers produced five components that comprise life meanings arranged in 34 items.
\end{abstract}

Keywords: meaning in life, overseas student

\section{PENDAHULUAN}

Sebagian besar mahasiswa identik dengan perantau, lokasi universitas yang tersebar di kota-kota besar Indonesia dengan tingkat kualitas berbeda-beda memunculkan pandangan berbeda pada masing-masing calon mahasiswa dalam menentukan pilihan universitas. Bercampurnya mahasiswa dengan identitas budaya yang berbeda-beda dalam suatu daerah bukanlah hal baru yang terjadi di Indonesia. Hal tersebut disebabkan oleh tingginya tingkat gerak sosial geografis seorang individu atau kelompok individu di atas kemajemukan budaya, suku bangsa, agama, bahasa, adat istiadat dan sebagainya. Sehingga hal tersebut memungkinkan terjadinya kontak budaya di antara penduduk Indonesia. Maka tidak heran jika potensi terjadinya kekagetan budaya di antara para individu perantau yang tinggal di suatu daerah baru akan semakin besar. Pada tahap awal kehidupannya di tempat rantauan, ia akan mengalami masalah ketidaknyamanan terhadap lingkungan baru. Reaksi ketika berpindah dan hidup dengan lingkungan baru, terutama yang memiliki kondisi budaya yang berbeda akan mempengaruhi perubahan fisik dan emosional. Budaya yang baru dapat berpotensi pada timbulnya tekanan, karena memahami dan menerima nilai-nilai budaya lain bukanlah hal yang instan dan kadangkala tidak berjalan dengan mudah.

Lingkungan baru yang dihadapi oleh mahasiswa rantau dapat memberikan dampak positif dan negatif terhadap perkembangan dirinya. Salah satu hal yang 
dapat dikembangkan atau didapatkan dari perantauan ini adalah makna hidup. Pemaknaan hidup pada manusia dapat di hadirkan dari berbagai macam peristiwa, salah satunya adalah masuknya seseorang ke dalam lingkungan baru yang membuat individu memiliki pandangan yang baru ataupun pengalaman yang baru terhadap budaya tersebut. Makna hidup seseorang dapat ditemui melalui berbagai macam pengalaman kehidupan baik itu yang negatif maupun pengalaman yang positif. Makna hidup adalah hal-hal yang oleh manusia dipandang penting, dirasakan berharga dan diyakini sebagai sesuatu yang benar serta dapat dijadikan tujuan hidupnya (Bastaman, 2007). Selanjutnya Frankl (2003) berpendapat bahwa kebermaknaan hidup individual manusia senantiasa terkait dengan kualitas penghayatan tentang tujuan hidupnya. Penghayatan ini menyebabkan adanya peningkatan tegangan-tegangan batin dalam dirinya, karena mencapai kehidupan yang bermakna itu membutuhkan perjuangan-perjuangan yang tidak kenal lelah.

Masalah yang pertama muncul dalam praktek pengukuran adalah seberapa baik instrumen (alat ukur) yang dibuat dalam penelitian ini valid (akurat) dan reliabel (dapat dipercaya). Oleh karena itu, perlu dilakukan uji validitas dan reliabilitas dari masing-masing skala sehingga skala yang digunakan dalam penelitian ini akurat dan dapat dipercaya. Oleh karenanya perlu dilakukan pengukuran terhadap realibilitas alat ukur. Pada artikel ini, akan membahas mengenai instrumen skala makna hidup yang akan ditinjau berdasarkan analisis faktor eksploratori dari teori yang dikemukakan oleh Bastaman (2007). Instrumen ini mengukur bagaimana mahasiswa rantau memaknai hidupnya di budaya yang baru, yaitu di kota tempat ia merantau. Instrumen ini berisi 36 item yang mengukur makna hidup yang terbagi dalam 6 aspek yaitu changing attitude, self insight, social support, the meaning of life, self commitment, dan directed activities. Pengukuran makna hidup telah di munculkan oleh beberapa skala seperti The
Purpose in Life Test (PIL test), Kuesioner Frankl, The Allport Vernon Lindzey Scale of Value (A-V-L) (Koeswara, 2007), Meaning in Life Questionnaire (MLQ) (Rose, Zask, \& Burton, 2016). Namun, kuesioner dan juga alat tes ini mengambil rujukan teori barat yaitu teori Frankl. Pada instrumen skala yang dibuat kali ini, menggunakan teori yang dicetuskan oleh Bastaman yang lebih mencerminkan budaya timur, sehingga peneliti menggunakan teori ini untuk membuat instrumen. Peneliti menggunakan teori Bastaman dikarenakan subyek yang akan diukur juga berasal dari budaya timur, yang diharapkan mampu menggambarkan kondisi budaya timur.

\section{Makna Hidup}

Karakteristik makna hidup menurut Bastaman (2007) antara lain: 1) makna hidup sifatnya unik, pribadi, dan temporer, artinya apa yang dianggap berarti oleh seseorang belum tentu berarti pula bagi orang lain. Makna hidup seseorang dan apa yang bermakna bagi dirinya biasanya sifatnya khusus, berbeda dan tak sama dengan makna hidup orang lain, dan dapat berubah dari waktu ke waktu. Mengingat keunikan dan kekhususannya itu, makna hidup tidak dapat diberikan oleh siapa pun, melainkan harus dicari, dijajagi, dan ditemukan sendiri. 2) Spesifik dan nyata, artinya makna hidup benar-benar dapat ditemukan dalam pengalaman dan kehidupan sehari-hari, serta tidak perlu selalu dikaitkan dengan hal-hal yang serba abstrak-filosofis, tujuan-tujuan idealistis, dan prestasi-prestasi akademis yang serba menakjubkan. 3) Memberi pedoman dan arah, artinya makna hidup yang ditemukan oleh seseorang akan memberikan pedoman dan arah terhadap kegiatan-kegiatan yang dilakukannya sehingga makna hidup seakan-akan menantang (challenging) dan mengundang (inviting) seseorang untuk memenuhinya.

Filsuf dan psikolog eksistensial berpendapat bahwa pengalaman makna dalam hidup terletak pada inti eksistensi manusia itu sendiri. Sebagian besar peneliti menurut Ryff (Majerníková \& 
Obročníková, 2017) mendefinisikan makna hidup sebagai kepercayaan individu di mana ia dapat merasakan alam semesta dan kehidupannya bermakna. Keterbatasan eksistensi kita dan kepastian akan kematian dapat menambah makna hidup. Bastaman (1996) menyatakan bahwa makna hidup (the meaning of life) dan hasrat untuk hidup bermakna (the will to meaning) merupakan motivasi utama manusia untuk meraih taraf kehidupan bermakna (the meaningfull life). Crumbaugh dan Maholick (Koeswara, 1992) mengatakan bahwa kebermaknaan hidup adalah seberapa tinggi individu mengalami hidupnya bermaksud atau bermakna. Makna hidup yang dimaksud merupakan segala sesuatu yang dipandang penting dan berharga, memberikan nilai khusus dan dijadikan tujuan hidup seseorang (Bastaman, 1996). Frankl (2003) mengungkapkan kebermaknaan hidup sebagai keadaan yang menunjukkan sejauhmana seseorang telah mengalami dan menghayati kepentingan keberadaan hidupnya menurut sudut pandang dirinya sendiri.

Frankl (Koeswara, 2007) menyampaikan kebermaknaan hidup dipengaruhi oleh kehidupan keagamaan dan filsafat sekuler, aktivitas pekerjaan, menyukai dan menghayati kehidupan sebagai wujud keindahan, cinta kepada sesama, dan pengalaman. Sedangkan Bastaman (2007) berpendapat bahwa faktor yang mempengaruhi kebermaknan hidup adalah kualitas insani, encounter, dan pemenuhan nilai-nilai kehidupan dalam mengatasi, menerima, dan menemukan makna dari penderitaan. Bastaman (2007) juga menjelaskan keberhasilan individu mengembangkan penghayatan hidup bermakna dilakukan dengan menyadari dan mengaktualisasikan potensi-potensi kualitas insani melalui berbagai kegiatan yang terarah pada pemenuhan makna hidup. Bentuk aktualisasi dari berbagai potensi kualitas insani yang langsung berkaitan dengan masalah penemuan makna hidup merupakan wujud penerimaan diri karena dengan memiliki penerimaan diri akan dapat mengembangkan diri ke arah gambaran yang sesuai dengan keinginan dan mampu melakukan komitmen dengan hal-hal seperti seperti nilai-nilai yang dianggap penting dan bermakna untuk dipenuhi, sebab setiap individu memiliki tanggung jawab mengembangkan dirinya dan menemukan makna hidupnya.

Makna hidup merupakan sesuatu yang muncul secara intrinsik dari diri manusia sendiri. Manusia harus memenuhi kebutuhan dasarnya terlebih dahulu untuk memenuhi nilai-nilai diri dalam hidupnya. Bila kebutuhan-kebutuhan dasar telah terpenuhi, maka nilai-nilai itu akan menjadi energi motivasional bagi individu untuk mendedikasikan diri pada usaha memenuhi nilai-nilai tersebut. Apabila individu memilih melakukan aktivitas-aktivitas yang sesuai dengan nilai-nilai intrinsik dalam dirinya, maka ia akan mendapatkan makna hidup yang bernilai positif dan menyehatkan bagi perkembangan kepribadian. Makna hidup menurut Maslow tak lain adalah meta motive, meta-needs atau growth need, yaitu suatu kebutuhan yang muncul dalam diri manusia untuk meraih tujuan, melanjutkan kehidupan, dan menjadi individu yang lebih baik. Manusia harus memenuhi basic needsnya terlebih dahulu, sebelum berusaha memenuhi growth needs. Manusia yang telah terpenuhi kebutuhan dasarnya, tapi tidak berhasil memenuhi nilai-nilai dalam dirinya akan menjadi sakit. Manusia yang berhasil menemukan makna hidupnya akan merasa dirinya penting dan bermakna (Debats, Drost, \& Hansen, 1995). Chaplin (2006) dalam kamus psikologi, makna mempunyai arti sebagai sesuatu yang diharapkan atau sesuatu yang menunjukkan pada sesuatu istilah tertentu.

Makna hidup menurut Seligman (2002) dapat dihasilkan atau ditemukan ketika seorang individu telah memiliki kehidupan yang baik dan bermakna yang di dalamnya terdapat komitmen yang kuat terhadap diri dan menghasilkan rasa positif dalam diri. Seligman (2002) mengatakan bahwa, ada tiga jalur utama menuju kebahagiaan. Rute pertama yaitu kenikmatan hidup, hal ini menghasilkan 
kebahagiaan jangka pendek. Sedangkan dua rute lainnya menghasilkan bentuk kepuasan yang lebih lama dan lebih dalam. Rute kedua, yaitu kehidupan yang baik, melibatkan keterlibatan mendalam dalam aktivitas di mana seseorang unggul dan merasakan flow dalam prosesnya, dan yang ketiga, yaitu kehidupan yang bermakna, melibatkan arah menuju tujuan atau pemikiran yang memberi rasa komitmen terhadap sesuatu yang lebih besar dari diri sendiri. Dengan cara ini, seseorang menunjukkan kepedulian terhadap dunia di luar diri yang diperlukan untuk mencapai bentuk kehidupan yang paling langgeng. Mengejar suatu tujuan hidup ataupun makna hidup melibatkan aspek keduanya, kehidupan yang baik dan kehidupan yang berarti. Kedua hal ini pun secara tidak langsung berkaitan erat dengan kesejahteraan subjektif

Makna pada diri adalah ekspresi dari nilai yang orang tempatkan pada peristiwa dan perjalanan kehidupan yang memiliki signifikansi yang melekat pada keberadaan mereka. Makna pada diri merupakan sistem kognitif yang dibangun secara individual dan berbasis pada budaya yang memengaruhi pilihan kegiatan dan tujuan seseorang, memberi kehidupan dengan tujuan, nilai pribadi yang diyakini, dan kepuasan diri.

Dengan demikian makna hidup dapat diartikan sebagai sesuatu yang muncul dari dalam diri sebagai arah tujuan dalam hidup untuk menemukan suatu istilah yang dianggap bermakna. Kebermaknaan dicapai oleh masing-masing individu terkait dengan apa yang sudah ia capai dan ia jalani dalam hidupnya. Selain itu, di dalam makna hidup juga terdapat komitmen yang lebih besar dari diri sendiri dan makna itu dapat dihadirkan dari peristiwa yang membahagiakan dan juga peristiwa yang kurang diinginkan dalam hidup.

\section{Faktor-faktor Makna Hidup}

Komponen-komponen yang menentukan tercapainya makna hidup, sesuai dengan komponen-komponen yang dikemukakan oleh Bastaman (2007), yaitu: a)
Pemahaman diri (self-insight): menyadari keadaan yang buruk saat ini dan berusaha untuk melakukan perbaikan; b) Makna hidup (the meaning of life): nilai-nilai yang dianggap penting yang berperan sebagai tujuan hidup dan pedoman hidup yang harus dipenuhi; c) Pengubahan sikap (changing attitude) yang semula tidak tepat menjadi lebih tepat dalam menghadapi masalah atau musibah yang tak terelakkan; d) Komitmen diri (self commitment), memiliki komitmen yang kuat dalam memenuhi makna hidup yang telah ditentukan; e) Kegiatan yang terarah (directed activities), segala upaya yang dilakukan demi meraih makna hidup dengan berbagai pengembangan minat, potensi, dan kemampuan positif; f) Dukungan sosial (social support), merupakan dukungan dari seseorang atau sejumlah orang yang dipercaya dan bersedia serta mampu memberikan dukungan dan bantuan jika diperlukan.

Huijbers (1987) menyatakan terdapat empat pokok yang terpenting dalam menentukan makna hidup, yakni: a) tempat manusia di dunia, b) nilai dunia bagi hidup manusia, c) nilai manusia sendiri, dan d) kebijaksanaan yang tepat guna menentukan jalan hidup yang benar. Bastaman (Rachman dan Laskmiwati, 2014) menyatakan bahwa mengenali dan memahami diri sangat bermanfaat untuk mengembangkan potensi-potensi dan segisegi positif serta usaha dalam mengurangi segi-segi negatif dalam diri individu. Individu yang memahami dirinya mampu menerima dan menghargai dirinya serta kehidupannya berdasarkan nilai-nilai yang diyakini dan dianggap berharga oleh individu itu sendiri. Demikian penilaian individu terhadap dirinya memiliki kaitan erat terhadap kehidupannya, serta usaha individu dalam menemukan makna hidup.

Kebermaknaaan hidup dapat diukur menggunakan skala kebermaknaan hidup dengan aspek-aspek: a) makna hidup, yaitu segala sesuatu yang dijadikan tujuan hidup, b) kepuasan hidup, yaitu sejauhmana seseorang dapat menikmati dan merasa puas menjalani aktivitas, c) kebebasan 
berkehendak, yaitu mampu mengendalikan kebebasan hidup secara bertanggungjawab, d) sikap terhadap kematian, yaitu bagaimana seseorang berpandangan dan kesiapannya menghadapi kematian, e) pikiran tentang bunuh diri, adalah menghindari keinginan atau memikirkan melakukan bunuh diri, f) kepantasan hidup, yaitu pandangan tentang sesuatu yang dialami apakah pantas atau tidak (Koeswara, 1992).

Faktor-faktor makna hidup telah dijelaskan oleh beberapa tokoh dan faktorfaktor tersebut biasanya dimasukkan pula pada alat ukur untuk mengukur makna hidup seseorang. Dalam penelitian ini, peneliti akan menggunakan faktor makna hidup yang di jelaskan oleh Bastaman (2007).

Komponen-komponen yang menentukan tercapainya makna hidup, yaitu: (selfinsight). Pemahaman diri menyadari keadaan yang buruk saat ini dan berusaha untuk melakukan perbaikan. Dengan adanya pemahaman akan diri, seorang individu lebih mudah untuk memahami apa yang harus ia lakukan untuk menghadapi problem dalam hidupnya dan juga bagaimana ia harus bertindak terhadap sesuatu yang tidak sesuai dengan dirinya. Pemahaman akan diri, menjadikan individu memahami kekurangan dan kelebihan yang ia miliki dan menjadikannya sebagai poin untuk menjalani hidupnya.

Kedua adalah Makna hidup (the meaning of life). Makna hidup merupakan nilai-nilai yang dianggap penting yang berperan sebagai tujuan hidup dan pedoman hidup yang harus dipenuhi. Makna hidup ini didapatkan secara individual. Makna hidup adalah sesuatu yang unik karena berbeda-beda pada tiap individu. Makna hidup adalah sesuatu yang fundamental pada hidup seseorang.

Selanjutnya adalah Pengubahan sikap (changing attitude). Pengubahan sikap merupakan bagaimana seseorang yang dapat mengubah sikapnya sesuai dengan tuntutan kehidupan dan tidak melupakan norma-norma yang terikat pada dirinya. Perngubahan sikap yang semula tidak tepat menjadi lebih tepat dalam menghadapi masalah atau musibah yang tak terelakkan. Pengubahan sikap merupakan salah satu strategi yang dimiliki individu untuk beradaptasi terhadap tuntutan kehidupan dan juga dinamika hidup.

Komitmen diri (self commitment). Komitmen diri adalah sesuatu yang mengikat individu untuk melakukan sesuatu yang sesuai dengan sasaran atau tujuan yang ingin dituju. Adanya komitmen diri pada individu membuat ia dapat mematangkan tekad untuk mencapai sesuatu yang menjadi tujuan sekalipun individu tersebut belum mengetahui bagaimana hasil akhirnya. Komitmen pada diri juga merupakan langkah yang diambil untuk memulai suatu tindakan tertentu yang sudah diniatkan sepenuh hati. Dengan adanya komitmen, individu akan lebih gigih dalam mencapai tujuan yang menjadi sasarannya dan juga termotivasi akan hal tersebut. Komitmen pada diri dipengaruhi pula oleh bagaimana minat individu terhadap sesuatu hal tersebut, lingkungan yang memengaruhi, motivasi yang dimiliki, dan kepercayaan pada kemampuan diri. Memiliki komitmen yang kuat juga dapat memenuhi makna hidup yang telah ditentukan melalui tujuan hidup yang ingin dicapainya.

Komponen kelima adalah kegiatan yang terarah (directed activities), segala upaya yang dilakukan demi meraih makna hidup dengan berbagai pengembangan minat, potensi, dan kemampuan positif. Makna hidup merupakan sesuatu yang ingin dicapai oleh individu melalui tujuan hidupnya. Dengan adanya kegiatan yang terarah, memudahkan individu untuk dapat mencapai tujuan hidupnya dan juga menemukan makna dalam hidupnya. Kegiatan yang terarah merupakan suatu wadah yang dapat mengembangkan pola pikir inividu terhadap sesuatu hal atau pun problem dalam hidupnya. Dengan adanya pola pikir yang baru, individu akan menemukan penyelesaian masalah atau pun insight untuk kehidupan di masa depannya.

Komponen keenam, dukungan sosial (social support). Dukungan sosial 
merupakan dukungan dari seseorang atau sejumlah orang yang dipercaya dan bersedia serta mampu memberikan dukungan dan bantuan jika diperlukan. Dukungan sosial merupakan suatu hal yang penting untuk individu dalam menjalani kesehariannya. Manusia adalah makhluk sosial di mana ia akan selalu bersosialisasi dan membutuhkan orang lain untuk melakukan hal-hal yang ada di dalam hidupnya. Adanya dukungan sosial, menjadikan individu lebih tegar dan kuat untuk menjalani problem-problem di dalam kehidupan. Dukungan sosial pun memeliki peran penting untuk pengembangan individu selain diri individu itu sendiri.

\section{METODE}

Penelitian ini pada dasarnya bertujuan untuk menguji validitas konstruk makna hidup menggunakan analisis faktor eksploratori (Suryabrata, 2009). Teori yang digunakan untuk menyusun instrumen skala makan hidup menggunakan teori Bastaman (1996) yang terdiri dari 6 aspek yaitu changing attitude, self insight, social support, the meaning of life, self commitment, dan directed activities. Keenam aspek ini di jabarkan melalui 36 item yang akan mengukur makna hidup pada mahasiswa rantau. Subyek penelitian berjumlah 50 orang yang merupakan mahasiswa rantau yang sedang menempuh studinya di Universitas Negeri Yogyakarta, dengan kriteria :

1. Mahasiswa aktif yang merantau ke Yogyakarta

2. Sudah merantau ke Yogyakarta minimal 2 tahun

3. Mampu baca-tulis

4. Bersedia berpartisipasi dalam penelitian.

Penelitian ini menggunakan dua tahap uji validitas, yaitu validitas isi dan validitas konstruk (Azwar, 2002). Validitas isi dilakukan melalui pendapat profesional. Validitas konstruk dilakukan dengan dua cara, yaitu melihat korelasi item-total dan menggunakan analisis faktor. Korelasi item-total digunakan untuk menseleksi item-item valid. Besaran koefesian korelasi yang memenuhi syarat untuk dapat diterima ialah 0,3 dengan tetap mempertimbangkan keterwakilan item. Jika suatu item sangat mewakili konsep yang akan diukur, maka item tersebut tetap dipertahankan meskipun koefesien korelasinya lebih dari 0,3 (Azwar, 2009).

Langkah selanjutnya adalah dengan melakukan analisis faktor. Ada dua pendekatan dalam melakukan analisis faktor, yaitu analisis faktor eksploratory (EFA) dan analisis faktor konfirmatori (CFA) (Suhr, 2006).

a. Memilih Variabel; ada dua hal yang perlu dilakukan agar analisis faktor dapat dilaksanakan, yang pertama yaitu menentukan besaran nilai Barlett Test of Sphericity, yang digunakan untuk mengetahui apakah ada korelasi yang signifikan antar variabel, dan kedua adalah Keiser-Meyers-Oklin

(KMO) Measure of Sampling Adequacy, yang digunakan untuk mengukur kecukupan sampel dengan cara membandingkan besarnya koefisien korelasi yang diamati dengan koefisein korelasi parsialnya.

b. Ekstraksi Faktor dilakukan terhadap semua variabel.

c. Rotasi Faktor; Langkah berikut dalam analisis faktor adalah melakukan rotasi faktor untuk memaksimalkan pengelompokan variabel. Rotasi yang digunakan dalam penelitian ini adalah metode varimax karena metode ini berusaha memaksimalkan jumlah varians dalam muatan faktor. Sebuah variabel bisa jadi mempunyai muatan faktor atau faktor loading yang rata-rata tinggi atau rata-rata rendah dalam setiap variabelnya. Metode varimax berusaha untuk menjadikan muatan faktor menjadi tinggi atau mendekati 1 atau -1 pada salah satu faktor.

d. Penamaan Faktor; Penamaan faktor ditentukan oleh muatan faktor yang dijelaskan oleh faktor terhadap 
setiap variabel. Faktor pertama adalah faktor yang terbesar variansnya dalam menjelaskan variabel. Hal ini menunjukkan bahwa faktor pertama adalah faktor umum dari skala makna hidup.

e. Uji reliabilitas; Pendekatan estimasi reliabilitas yang digunakan dalam penelitian ini adalah reliabilitas konsistensi internal alphacronbach. Koefisien reliabilitas berkisar dari skor 0,00 hingga 1,00 dengan asumsi bahwa semakin mendekati angka 1,00 maka semakin reliabellah alat ukur tersebut.

f. Uji Validitas Isi; Uji validitas isi dilakukan melalui pendapat profesional. Dalam hal ini mengkomunikasikannya dengan sejumlah orang yang dipandang ahli dan memahami tugas dosen.

\section{HASIL DAN PEMBAHASAN}

Hasil

a. Memilih Variabel

Hasil perhitungan menunjukkan besaran nilai Barlett Test of Sphericity adalah 1261,374 dengan taraf signifikansi 0,000 yang berarti ada korelasi yang signifikan di antara variabel pengamat. Hasil perhitungan

KMO sebesar 0,611 $\quad(\mathrm{p}<0.000)$ menunjukkan bahwa adanya kecukupan sampel yang dapat digunakan dalam analisis faktor.

b. Ekstraksi Faktor

Ekstraksi faktor dilakukan terhadap semua variabel sehingga terdapat 34 aitem yang diekstraksi. Gambar 1 menunjukkan grafik scree plot. Berdasar pada grafik, tampak bahwa terdapat 10 komponen faktor dengan nilai kumulatif varians sebesar 79,206\%. Akan tetapi dijumpai bahwa sebaran aitem dalam10 komponen faktor tidak beraturan dan sulit diinterpretasikan, maka ditetapkan 5 komponen faktor dengan nilai kumulatif varians sebesar 60,451\%. Tabel 2 menjelaskan hasil ekstraksi faktor yang menghasilkan 5 faktor yang belum dirotasi dengan menggunakan metode ekstraksi Principal Component Analysis. Faktor pertama menjelaskan varians sebesar 30,561\%, faktor kedua $10,394 \%$, faktor ketiga 8,302\%, faktor keempat $6,008 \%$, dan faktor kelima 5,186\%.

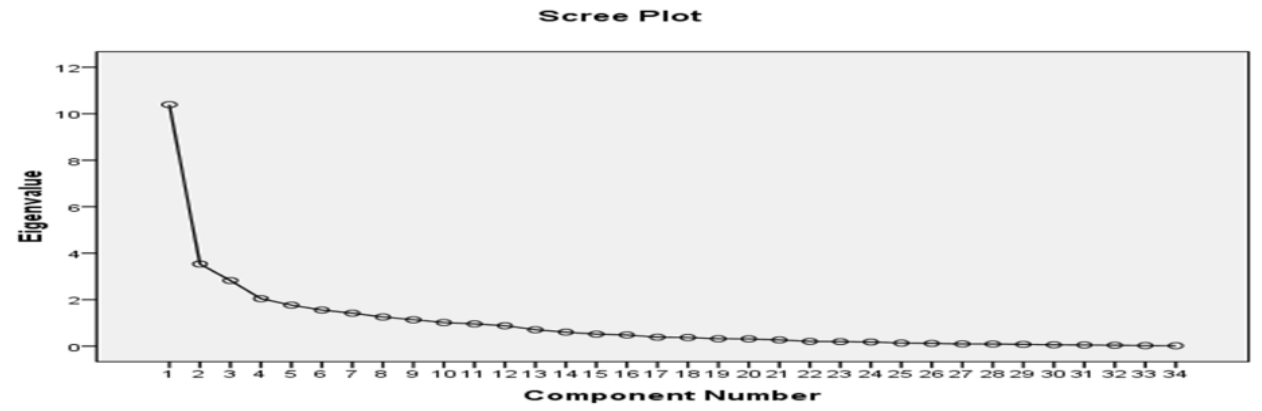

Gambar 1. Grafik Scree Plot

c. Rotasi Faktor

Hasil rotasi dengan metode varimax menghasilkan muatan-muatan faktor yang ditampilkan pada tabel 2 . 
Tabel 2. Faktor-faktor Terrotasi Skala Ikhlas

\begin{tabular}{|c|c|c|c|c|c|}
\hline Butir & $\begin{array}{l}\text { Self } \\
\text { Insight }\end{array}$ & $\begin{array}{l}\text { Dukunga } \\
\mathrm{n} \\
\text { keluarga }\end{array}$ & $\begin{array}{l}\text { Dukunga } \\
\text { n teman }\end{array}$ & $\begin{array}{l}\text { Kebermaknaa } \\
\mathrm{n} \text { hidup }\end{array}$ & $\begin{array}{l}\text { Pengembangan } \\
\text { diri }\end{array}$ \\
\hline item 2 & 0,846 & & & & \\
\hline item 3 & 0,169 & & & & \\
\hline item 4 & 0,542 & & & & \\
\hline item 5 & 0,803 & & & & \\
\hline item 7 & 0,52 & & & & \\
\hline item 12 & 0,474 & & & & \\
\hline item 13 & 0,564 & & & & \\
\hline item 14 & 0,755 & & & & \\
\hline item 27 & 0,247 & & & & \\
\hline item 29 & 0,614 & & & & \\
\hline item 30 & 0,486 & & & & \\
\hline item 31 & 0,166 & & & & \\
\hline item 15 & & 0,86 & & & \\
\hline item 16 & & 0,807 & & & \\
\hline item 17 & & 0,847 & & & \\
\hline item 28 & & 0,473 & & & \\
\hline item 18 & & & 0,724 & & \\
\hline item 19 & & & 0,596 & & \\
\hline item 29 & & & 0,786 & & \\
\hline item 22 & & & 0,7 & & \\
\hline item 23 & & & 0,51 & & \\
\hline item 1 & & & & 0,44 & \\
\hline item 24 & & & & 0,546 & \\
\hline item 25 & & & & 0,581 & \\
\hline item 26 & & & & 0,371 & \\
\hline item 33 & & & & 0,821 & \\
\hline item 34 & & & & 0,537 & \\
\hline item 6 & & & & & 0,182 \\
\hline item 8 & & & & & 0,765 \\
\hline item 9 & & & & & 0,709 \\
\hline item 10 & & & & & 0,343 \\
\hline item 11 & & & & & 0,557 \\
\hline item 21 & & & & & 0,584 \\
\hline item 32 & & & & & 0,498 \\
\hline $\begin{array}{l}\text { Varians yang } \\
\text { dijelaskan }\end{array}$ & 10,391 & 3,534 & 2,823 & 2,043 & 1,763 \\
\hline Varians dalam \% & 30,561 & 10,394 & 8,302 & 6,008 & 5,186 \\
\hline $\begin{array}{l}\text { Kumulatif varians } \\
\text { dalam } \%\end{array}$ & 30,561 & 40,955 & 49,257 & 55,265 & 60,451 \\
\hline
\end{tabular}


d. Penamaan Faktor

Item yang termasuk ke dalam faktor pertama dengan melihat besarnya faktor loading adalah 2, 3, 4, 5, 7, 12, 13, 14, 27, 29, 30, dan 31 . Berdasarkan pada konten pernyataannya maka faktor pertama dinamakan pengetahuan mengenai diri sendiri atau self insight. Item yang termasuk ke dalam faktor kedua adalah 15, 16, 17, dan 28. Berdasarkan konten pernyataannya maka faktor kedua dinamakan dukungan keluarga. Faktor ketiga terdiri dari item 18, 19, 20, 22, dan 23, kemudian berdasar konten pernyataannya diberi nama dukungan teman. Faktor keempat terdiri dari item 1, 24, 25, 26, 33, dan 34, yang kemudian dengan memperhatikan konten pernyataannya diberi nama pandangan mengenai kehidupan. Faktor kelima terdiri dari item 6, 8, 9, 10, 11, 21, dan 32, konten ini diberikan nama pengembangan diri. Dengan demikian, dapat disimpulkan bahwa skala makna hidup terdiri dari 5 dimensi atau faktor yang meliputi pengetahuan mengenai diri sendiri atau self insight, dukungan keluarga, dukungan teman, pandangan mengenai kehidupan, dan pengembangan diri.

e. Uji Reliabilitas

Estimasi reliabilitas seluruh item dalam skala ikhlas menghasilkan skor alpha 0,924. Koefisien ini menunjukkan bahwa skala makna hidup memiliki reliabilitas yang baik dan dapat dipercaya hasil pengukurannya.

f. Uji Validitas Isi; peneliti meminta pendapat melalui rekan-rekan sesama mahasiswa sebanyak 10 orang untuk melakukan penilaian terhadap skala yang telah peneliti buat. Uji validitas isi dilakukan melalui uji validitas Aiken yang menghasilkan nilai sebesar >0,867. Nilai ini mengindikasikan bahwa butir-butir yang telah dibuat oleh peneliti layak untuk digunakan.

\section{Pembahasan}

Masalah yang pertama muncul dalam praktek pengukuran adalah seberapa baik instrumen (alat ukur) yang dibuat dalam penelitian ini valid (akurat) dan reliabel (dapat dipercaya). Oleh karena itu, perlu dilakukan uji validitas dan reliabilitas dari masing-masing skala sehingga skala yang digunakan dalam penelitian ini akurat dan dapat dipercaya. Oleh karenanya perlu dilakukan pengukuran terhadap reliabilitas alat ukur. Pada artikel ini, peneliti membahas mengenai validitas isi dan konstruk pada instrumen skala makna hidup. Instrumen skala makna hidup yang akan ditinjau berdasarkan analisis faktor eksploratori dari teori yang dikemukakan oleh Bastaman. Instrumen ini mengukur bagaimana mahasiswa rantau memaknai hidupnya di budaya yang baru, yaitu di kota tempat ia merantau. Instrumen ini berisi 36 item yang mengukur makna hidup yang terbagi dalam 6 aspek yaitu changing attitude, self insight, social support, the meaning of life, self commitment, dan directed activities. Namun, dikarenakan pada saat mengukur validitas isi ada 2 item yang kurang mendukung dan memiliki nilai Aiken yang kecil, maka peneliti menghapus 2 item tersebut.

Pengukuran makna hidup telah dimunculkan oleh beberapa skala seperti The Purpose in Life Test (PIL test), Kuesioner Frankl, The Allport Vernon Lindzey Scale of Value (A-V-L) (Koeswara, 2007), Meaning in Life Questionnaire (MLQ) (Rose, Zask, dan Burton, 2016). Namun, kuesioner dan juga alat tes ini mengambil rujukan teori barat yaitu teori Frankl. Pada instrumen skala yang dibuat kali ini, menggunakan teori yang dicetuskan oleh Bastaman yang lebih mencerminkan budaya timur, sehingga peneliti menggunakan teori ini untuk membuat instrumen. Peneliti menggunakan teori Bastaman dikarenakan subyek yang akan diukur juga berasal dari budaya timur, yang diharapkan mampu menggambarkan kondisi budaya timur. 
Instrumen skala makna hidup setelah diujikan dalam SPSS dengan melihat rotasi dan penyebaran komponennya, maka didapatkan 5 komponen yaitu pengetahuan mengenai diri sendiri atau self insight, dukungan teman, dukungan keluarga, pandangan hidup, dan pengembangan diri. Komponen ini lebih sedikit dibandingkan dengan teori awal yang digunakan. Pada teori awal yang digunakan mengacu pada teori Bastaman (1996) yang berisikan 6 faktor makna hidup. Namun, setelah diujicobakan 6 komponen ini menyatu menjadi 5 komponen dengan nama komponen yang baru. Sehingga dari hasil analis faktor eksploratori, instrumen makna hidup ini menghasilkan 5 komponen.

Dalam uji coba instrumen ini, menggunakan mahasiswa rantau yang sudah merantau selama 2 tahun. Hal ini juga dapat menjadi penyebab mengapa instrumen memiliki komponen yang lebih sedikit dan dengan nama-nama yang lebih spesifik pada kriteria perantau. Selain itu, instrumen ini juga diharapkan bisa diujicobakan kembali pada subyek yang berbeda agar dapat mengetahui apakah instrumen ini memiliki reliabilitas yang baik apa bila diujikan pada subyek yang memiliki latar yang berbeda. Walaupun angka reliabilitas yang didapatkan sudah tinggi, namun uji coba selanjutnya dengan subyek yang berbeda tetap diharapkan untuk dilaksanakan.

\section{PENUTUP}

Budaya yang baru dapat berpotensi pada timbulnya tekanan, karena memahami dan menerima nilai-nilai budaya lain bukanlah hal yang instan dan kadangkala tidak berjalan dengan mudah. Dengan adanya pemaknaan hidup terhadap peristiwa yang dilalui oleh individu tersebut ia dapat beradaptasi dengan baik pada situasi yang baru. Pemaknaan hidup pada mahasiswa rantau dapat di ukur melalui instrumen pemaknaan hidup yang penulis telah ujikan dalam SPSS dengan melihat rotasi dan penyebaran komponennya. Hasil pengujian didapatkan 5 komponen yaitu pengetahuan mengenai diri sendiri atau self insight, dukungan teman, dukungan keluarga, pandangan hidup, dan pengembangan diri. Komponen ini lebih sedikit dibandingkan dengan teori awal yang digunakan. Teori awal yang mengacu pada teori Bastaman (1996) berisikan 6 faktor makna hidup. Namun, setelah diujicobakan 6 komponen ini menyatu menjadi 5 komponen dengan nama komponen baru. Sehingga dari hasil analis faktor eksploratori, instrumen makna hidup menghasilkan 5 komponen.

\section{DAFTAR PUSTAKA}

Azwar, S. (2002). Penyusunan skala psikologi. Yogyakarta: Pustaka Pelajar.

Azwar, S. (2009). Efek seleksi item berdasar daya diskriminasi terhadap reliabilitas skor tes. Buletin Psikologi, 17(1), 28-32.

Bastaman, H.D. (1996). Meraih hidup bermakna :kisah pribadi dengan pengalaman tragis. Jakarta: Paramadina.

Bastaman, H.D. (2007). Logoterapi: Psikologi untuk menemukan makna hidup dan meraih hidup bermakna. Jakarta: PT. Raja Grafindo.

Chaplin, C.P. (2006). Kamus lengkap psikologi. Jakarta: PT. Rajawali Press.

Debats, D. L., Drost, J., \& Hansen, P. (1995). Experiences of meaning in life - A combined qualitative and quantitative approach. British Journal of Psychology, 86, 359-375.

Frankl, V. E. (2003). Logoterapi terapi psikologi melalui pemaknaan eksistensi. Yogyakarta: Kreasi wacana.

Huijbers, T. (1987). Manusia merenungkan dunianya. Yogyakarta: Kanisius.

Koeswara. (2007). Legoterapi, psikoterapi Viktor Frankl. Yogyakarta: Kanisius.

Koeswara, E. (1992). Logoterapi: psikoterapi Viktor Frankl. Yogyakarta: Kanisius.

Majerníková, L., \& Obročníková, A. (2017). Relationship between the quality of life and the meaning of life 
in cancer patient. Vol . 16 issue 2, ttps://doi.org/10.1515/pielxxiw2017-0012.

Rachman, S. A., \& Laksmiwati, H. (2014). Hubungan konsep diri dan makna hidup pada anak jalanan. Character, Volume 03 Nomor 2.

Rose, L. M., Zask, A, Burton L.J. (2016). Psychometric Properties of the Meaning in Life Questionnaire (MLQ) in a sample of Australian adolescents. International Journal of Adolescence and Youth. No 22, issue 1, pp. 68-77.

Seligman, M.E.P. (2002). Authentic happiness. New York: Free Press.

Suhr, D.D. (2006). Exploratory or confirmatory factor analysis?.Colorado: SAS Institute Inc.

Suryabrata, S. (2009). Metodologi penelitian. Jakarta: PT. RajaGrafindo Persada. 